\title{
RELATIVE ROLES OF GENETIC AND ENVIRONMENTAL FACTORS IN THE CONTROL OF SERUM URIC ACID LEVELS IN NORMOURICAEMIC SUBJECTS
}

\author{
BY
}

JAMES A. BOYLE, WILLIAM R. GREIG, MUKUNDRAI K. JASANI, ANNE DUNCAN, ? MICHAEL DIVER, AND W. WATSON BUCHANAN

From the Centre for Rheumatic Diseases, Glasgow, the University Department of Medicine, and the Department of Biochemistry, Royal Infirmary, Glasgow, Scotland

Gout has long been thought to be hereditary and several genetic hypotheses have been proposed for the occurrence of hyperuricaemia (Smyth, Cotterman, and Freyberg, 1948; Stecher, Hersh, and Solomon, 1949; Hauge and Harvald, 1955). Blumberg (1965), in a critical review of these studies, has concluded that they are far from ideal in testing a genetic hypothesis, and comments that this may be why such studies have provided inconsistent results. Indeed, recently, O'Brien, Burch, and Bunim (1966), in a carefully controlled epidemiological study of the Blackfeet Indians in Montana and the Pima Indians in Arizona, showed that the trait of hyperuricaemia "is for the most part not a genetic one but is instead largely determined by environmental factors". These authors, did, however, note some familial aggregation of hyperuricaemia, but genetic analysis was not consistent with either a simple recessive or dominant inheritance; analysis of a polygenic trait indicated a rather low heritability.

It occurred to us that it might be of interest, in view of the present controversy surrounding the genetics of gout and hyperuricaemia, to ascertain the strength of the genetic and environmental components in the control of the serum uric level in normouricaemic subjects.

To do this we have adopted the twin study method where the mean intrapair variance of serum uric acid levels observed in monozygotic (MZ) (genetically-identical) twin pairs has been contrasted with the mean intrapair variance of serum uric acid levels in dizygotic (DZ) (genetically non-identical) twin pairs and the results of this comparison have been analysed by calculating the variance ratio and assessing its significance on the $F$ ratio, as has been described by Osborne and De George (1959).

\section{Material and Methods}

112 twin pairs were studied. The methods of ascertainment and determination of zygosity have been described in detail elsewhere (Buchanan, Boyle, Greig McAndrew, $\omega$ Barr, Anderson, and Goudie, 1966; Greig, Boyle, Duncan, w Nicol, Gray, Buchanan, and McGirr, 1967). The 을 likelihood of a correct diagnosis of monozygosity is greater than 90 per cent. for every twin pair accepted as $\vec{z}$ being $M Z$ in the present study (Dencker, Hauge, Kaij, and Nielsen, 1961), and in the case of the DZ twins the likelihood of a correct diagnosis is 100 per cent. because $\vec{\theta}$ dizygosity was diagnosed only when there was unequivocal evidence, such as different iris colour or blood group antigen. The ascertainment campaign which was used to obtain twins mentioned rheumatoid arthritis, but did not mention gout, and no twins in this study had gout.

Each twin pair were seen together and blood samples 을 were taken at the same time in the non-fasting state. $\stackrel{\mathbb{2}}{2}$ None of the subjects had ingested alcohol on the day of $\overrightarrow{\overrightarrow{0}}$ the study but we have no information on the drugs, such as salicylates, which this essentially healthy population of twins might have been taking. As the numbers of twin pairs are fairly large we feel that, although it is possible that a few may have been taking salicylates or other drugs known to alter blood uric acid levels, it is unlikely that this factor would be of much importance in influencing the conclusions of the study. None of the twins had clinically apparent disease, all had normal blood pressures $ᄋ$ and all but eleven individuals had a serum creatinine level $<1.00 \mathrm{mg}$. per cent. These eleven individuals have been 윽 included in the study since none had evidence of renal $>$ disease; and these subjects presumably are reasonably representative of the normal population.

The numbers of twin pairs studied in this investigation $\mathrm{N}$ are shown in Table I (overleaf). The breakdown of the $\mathrm{N}$ 112 twin pairs studied according to sex and zygosity $\mathrm{N}$ shows an increase in the number of MZ female twin pairs, $\omega$ which has been the experience of other workers who have $\overline{-}$ obtained twins by an ascertainment campaign (Osborneco and De George, 1959). It can also be seen that the mean $\frac{}{\Phi}$ age and age ranges were similar in all groups. As no twins under the age of 12 years were studied it will be $\square$ appreciated from the mean and standard deviation of the $\bar{O}$ ages that the majority were young; indeed, 71 twin pairs $\overrightarrow{\mathbb{D}}$ were under the age of 20 years.

The serum uric levels were determined by an automated $\stackrel{\mathbb{Q}}{\varrho}$ colorimetric method using the Technicon Auto Analyser $\bar{x}$ 
TABLE I

RESULTS OF SERUM URIC ACID DETERMINATIONS IN 112 TWIN PAIRS

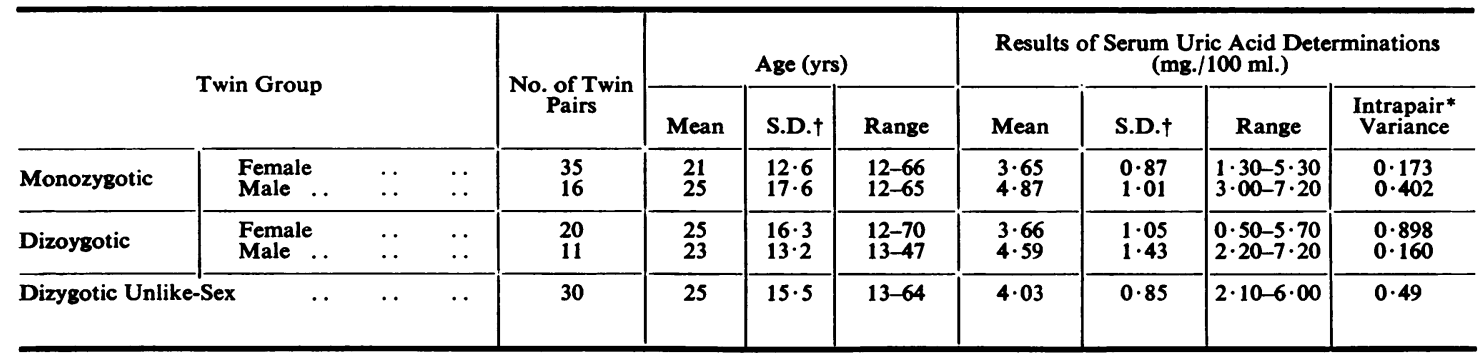

+S.D. = Standard Deviation

* See text for explanation of how this function was calculated.

Method No. 22. All sera were stored at $-20^{\circ} \mathrm{C}$. for 3 weeks before estimation of the serum uric acid, because Buchanan, Isdale, and Rose (1965) have shown that chromogens present in fresh sera which give a falsely high reading in colorimetric methods measuring uric acid largely disappear from the sera after storage for 3 weeks in the frozen state.

The calculation of interpair variances for the twins was performed as described by Osborne and De George (1959). Essentially the method contrasts the variance of the sums of differences between $M Z$ twins with the variance observed for these functions in $\mathrm{DZ}$ twins. The significance of the resulting figure is tested on the $F$ ratio distribution. Full details of this method are described by Osborne and De George (1959) and Mathers, Osborne, and De George (1961). Allen (1966), in a review of the problems in twin research, has commented that when one is dealing with the continuous variables the variance ratio method is preferable to the heritability index which we have used for dealing with discrete variables in previous studies (Buchanan and others, 1966; Greig and others, 1966).

\section{Results}

The results are summarized in Tables I and II.

The mean serum uric acid levels were 3.65 and $3.66 \mathrm{mg} . / 100 \mathrm{ml}$. for the $\mathrm{MZ}$ and $\mathrm{DZ}$ female twin pairs respectively, and 4.87 and $4.59 \mathrm{mg}$. $/ 100 \mathrm{ml}$. for the $M Z$ and $D Z$ male twin pairs respectively.

The range of serum uric acid levels in female twins

TABLE II

SIGNIFICANCE VALUES FOR OBSERVED INTRAPAIR VARIANCES IN MALE AND FEMALE TWINS

\begin{tabular}{|c|c|c|c|c|}
\hline \multicolumn{2}{|c|}{ Twin Group } & Intrapair Variance* & F ratio* & $P$ value \\
\hline Female & $\begin{array}{l}\text { Monozygotic } \\
\text { Dizygotic }\end{array}$ & $\left.\begin{array}{l}0 \cdot 173 \\
0 \cdot 898\end{array}\right\}$ & $5 \cdot 19$ & $<0.001$ \\
\hline Male & $\begin{array}{l}\text { Monozygotic } \\
\text { Dizygotic }\end{array}$ & $\left.\begin{array}{l}0 \cdot 402 \\
0 \cdot 160\end{array}\right\}$ & 0.40 & $\begin{array}{c}\text { Not } \\
\text { significant }\end{array}$ \\
\hline
\end{tabular}

- See text for explanation of how this function was calculatod. was $0 \cdot 50-5 \cdot 7 \mathrm{mg} . / 100 \mathrm{ml}$. and in male twins $2 \cdot 2$ $7 \cdot 2 \mathrm{mg} . / 100 \mathrm{ml}$. The singularly low value of 0.5 mg./100 ml. was present in a 19-year-old female DZ twin. It has been shown that low serum uric acid levels are present as early as 12 weeks in normal pregnancy (Boyle, Campbell, Duncan, Greig, and Buchanan, 1966), and it may be that this twin was pregnant but we have no information on this point.

The intrapair variance of 0.173 in the $\mathrm{MZ}$ female twin pairs contrasts with the intrapair variance of 0.898 in the $\mathrm{DZ}$ female twin pairs. This comparison yields an $F$ ratio of $5 \cdot 19$ which is significant at the less than one in a thousand level (Table II).

The intrapair variance for the $\mathrm{MZ}$ male twin pairs $(0.402)$ was higher than the intrapair variance for the $\mathrm{DZ}$ male twin pairs $(0 \cdot 160)$, which is clearly not significant of a genetic component (Table II).

Table III (overleaf) contrasts the intrapair variance of serum uric acid levels in all twins, in twins living together in the same household, and twins living apart from each other for longer than one year. The mean intrapair variance in $\mathbf{M Z}$ female twins was 0.08 in those living together and 0.70 in those living apart. This difference is highly significant $(P<0.01)$ and is indicative of an environmental factor in control of serum uric acid level in females. For the DZ female twins these figures were 0.41 (living together) and 1.58 (living apart) which is further support of this conclusion. In MZ male twin pairs the variance was slightly higher in those living apart $(0.56)$ than in those living together $(0.33)$. The number of $\mathrm{DZ}$ male twin pairs living apart, however, was very small. Interpretation of the results in the unlike-sex DZ twin pairs is difficult because of the sex difference: the mean intrapair variance in those living apart was lower $(0.50)$ than those living together $(0 \cdot 82)$, but these differences are not statistically significant. 
TABLE III

MEAN INTRAPAIR VARIANCE* OF SERUM URIC ACID LEVELS IN TWINS LIVING TOGETHER AND IN TWINS LIVING APART (SEPARATED FOR 1 YEAR OR LONGER)

\begin{tabular}{|c|c|c|c|c|c|c|c|c|c|c|c|c|}
\hline & \multirow{3}{*}{ Twin Group } & & \multicolumn{5}{|c|}{ Twins Living Together } & \multicolumn{5}{|c|}{ Twins Living Apart } \\
\hline & & & \multirow{2}{*}{$\begin{array}{l}\text { No. of Twin } \\
\text { Pairs }\end{array}$} & \multicolumn{3}{|c|}{ Age (yrs) } & \multirow{2}{*}{$\begin{array}{l}\text { Intrapair } \\
\text { Variance* } \\
\text { of Serum } \\
\text { Uric Acid } \\
\text { Levels }\end{array}$} & \multirow{2}{*}{$\begin{array}{l}\text { No. of Twin } \\
\text { Pairs }\end{array}$} & \multicolumn{3}{|c|}{ Age (yrs) } & \multirow{2}{*}{$\begin{array}{c}\text { Intrapair } \\
\text { Variance* } \\
\text { of Serum } \\
\text { Uric Acid } \\
\text { Levels }\end{array}$} \\
\hline & & & & Mean & Range & S.D.† & & & Mean & Range & S.D.† & \\
\hline Female & $\begin{array}{l}\text { Monozygotic } \\
\text { Dizygotic . . }\end{array}$ & $\begin{array}{l}\ldots \\
\cdots\end{array}$ & $\begin{array}{l}29 \\
14\end{array}$ & $\begin{array}{l}18 \\
19\end{array}$ & $\begin{array}{l}12-50 \\
12-70\end{array}$ & $\begin{array}{r}7 \cdot 4 \\
15 \cdot 2\end{array}$ & $\begin{array}{l}0.08 \\
0.41\end{array}$ & $\begin{array}{l}6 \\
6\end{array}$ & $\begin{array}{l}37 \\
38\end{array}$ & \begin{tabular}{|l|}
$19-66$ \\
$27-50$
\end{tabular} & $\begin{array}{r}20 \cdot 4 \\
9 \cdot 4\end{array}$ & $\begin{array}{l}0 \cdot 70 \\
1 \cdot 58\end{array}$ \\
\hline Male & $\begin{array}{l}\text { Monozygotic } \\
\text { Dizygotic }\end{array}$ & $\begin{array}{l}\ldots \\
\ldots\end{array}$ & $\begin{array}{r}11 \\
8\end{array}$ & $\begin{array}{l}15 \\
15\end{array}$ & $\begin{array}{l}12-21 \\
13-17\end{array}$ & $\begin{array}{l}2 \cdot 7 \\
1 \cdot 7\end{array}$ & $\begin{array}{l}0 \cdot 33 \\
0 \cdot 16\end{array}$ & $\begin{array}{l}5 \\
3\end{array}$ & $\begin{array}{l}48 \\
43\end{array}$ & $\begin{array}{l}30-65 \\
37-47\end{array}$ & $\begin{array}{r}15 \cdot 6 \\
4 \cdot 9\end{array}$ & $\begin{array}{l}0 \cdot 56 \\
0 \cdot 15\end{array}$ \\
\hline \multicolumn{2}{|c|}{ Dizygotic Unlike-Sex } & $\ldots$ & 19 & 18 & 13-55 & $9 \cdot 2$ & 0.82 & 11 & 39 & $23-64$ & $4 \cdot 7$ & $0 \cdot 50$ \\
\hline
\end{tabular}

+S.D. = Standard Deviation

* See text for explanation of how this function was calculated

\section{Discussion}

To our knowledge only one previous study of serum uric acid levels in normal twins has been reported (Jensen, Blankenhorn, Chin, Sturgeon, and Ware, 1965). These authors studied thirteen MZ males, fourteen $M Z$ females, six DZ males, seven $\mathrm{DZ}$ females, and four unlike-sex DZ twins, and interpreted their findings as providing "more conclusive evidence for genetic control of . . . uric acid in normal man that has been available previously". Interpretation of their data, however, is difficult for the following reasons. The numbers studied were relatively small. They included four unlike-sex DZ twins when comparing the intrapair variance of $M Z$ to DZ twins. Such a procedure is unwarranted because the sex differences known to exist in serum uric acid levels make it likely that the intrapair variance of $D Z$ unlike-sex twins will be higher than the intrapair variance of either $M Z$ or $D Z$ like-sex pairs, as has been discussed by Osborne and De George (1959).

A factor which should cause hesitation before one too readily ascribes a significantly smaller intrapair variance in $\mathrm{MZ}$ compared with $\mathrm{DZ}$ twin pairs to the effects of genetic control of these variances, is the possibility that $\mathrm{MZ}$ twins may share a closer common environment than do DZ twins. The lower MZ intrapair variance might then merely be a refiection of this closeness of environment. It is unlikely that such considerations apply in the present study, for the significantly lower intrapair variance for serum uric acid values in MZ females compared with $D Z$ females, was not paralleled by the findings in the $M Z$ and $D Z$ male twins and the vast majority of twins of both sexes were living together at the time of the study. The composition of the 31 twin pairs living apart was as follows: six female MZ, six female $\mathrm{DZ}$, five male $\mathrm{MZ}$, three male $\mathrm{DZ}$, and eleven unlike-sex DZ pairs.

It could be argued that the fact that males have a higher serum uric acid level than females (Seegmiller, Laster, and Howell, 1963) might cause the intrapair difference to be greater in male twins than in female twins. However, as one is concerned with the ratio of the variances of the intrapair differences in $\mathbf{M Z}$ and DZ twins within each sex, this objection does not explain the strikingly high $F$ value found in the female twins compared with male twins.

It seems reasonable to conclude, therefore, that the smaller intrapair variance in the female MZ compared to $D Z$ twins almost certainly reflects a fairly strong genetic control of the variation in serum uric acid levels in females. The failure to demonstrate a genetic control of the normal serum uric acid level in the male does not mean that such control does not exist but merely that it is likely to be weak and that there is a very strong environmental factor (or factors) operating in males in control of the serum uric acid level.

Many environmental factors are now recognized in the control of serum uric acid levels and these have been discussed by Seegmiller, Laster, and Howell (1963). The results of the present study suggest that the mechanisms controlling the normal serum uric acid levels are more influenced by an environmental factor (or factors) in males, and that females are for some reason (either environmental or genetic) less susceptible to this factor. That variations in the level of serum uric acid in females are also influenced by environmental factors is clear from the study of intrapair variances in female twins living together and living apart (Table III).

The nature of this environmental factor (or factors) which predominates over genetic factors in males but not in females in controlling serum uric acid 
levels is not yet known, for no one has so far to our knowledge described a differing reaction between the sexes to an environmental influence on serum uric acid levels.

It is known that males have a higher uric acid level than females and that primary hyperuricaemia is commoner in men than in women. It is tempting to speculate that this situation may be partly explained by the reaction of males to environmental factors which women either do not meet or to which they are genetically less susceptible. The present study neither confirms nor refutes this speculation and it would clearly be of value in further work to document all cases of $\mathrm{MZ}$ males discordant for hyperuricaemia. If these were found in any numbers and the reason for the hyperuricaemia fully documented (whether overproducers or underexcretors of uric acid) our knowledge of the genetics of hyperuricaemia would be much enlarged.

\section{Summary}

Serum uric acid levels were estimated by an automated colorimetric method in 112 pairs of healthy twins from the Glasgow and West of Scotland area. Calculation of the intrapair variances in monozygotic and dizygotic twins showed a significant genetic component in the control of variation in the serum uric acid level in females. The study failed to detect a strong genetic component in males. The possibility that an environmental factor (or factors) plays an important role in the maintenance of the higher serum uric acid level found in males compared with females is discussed.

It is a pleasure to acknowledge the willing co-operation of the twins from the City of Glasgow and the West of Scotland area who responded so generously to our advertisement campaign. Our thanks are due to Dr. T. Scott Wilson, Medical Officer of Health for the Glasgow Corporation Education Department, Mr. I. Thorburn of the Evening Citizen, the British Broadcasting Corporation, and Scottish Television for help in the ascertainment of the twins. Our thanks are also due to Chief Superintendent D. Hamilton, Identification Bureau, City of Glasgow Police, for analysis of finger print patterns, and to Miss Hogg and Miss McLeish of the Women's Voluntary Service for help at the "Twin Clinic". We wish in particular to thank Dr. J. H. Renwick, Reader in Human Genetics, Department of Genetics, University of Glasgow.

This work was supported by a grant from the Arthritis and Rheumatism Council for Research in Great Britain.

One of us (M.K.J.) was the holder of a CIBA clinical research fellowship.

\section{REFERENCES}

Allen, G. (1966). "Twin research: problems and prospects", in "Progress in Medical Genetics", vol. 4, chap. 8, p.242. ed A. G. Steinberg and A. G. Bearn, Heinemann, London.

Blumberg, B. S. (1965). Arthr. and Rheum., 8, 627 (Heredity of gout and hyperuricemia).

Boyle, J. A., Campbell, S., Duncan, A. M., Greig, W. R., and Buchanan, W. W. (1966). J. clin. Path., 19, 501 (Serum uric acid levels in normal pregnancy with observations on the renal excretion of urate in pregnancy).

Buchanan, W. W., Boyle, J. A., Greig, W. R., McAndrew, R., Barr, M., Anderson, J. R., and Goudie, R. B. (1966). Ann. rheum. Dis., 25, 463. (The distribution of certain autoantibodies in monozygotic and dizygotic twins).

_- Isdale, I. C., and Rose, B. S. (1965). Ibid., 24, 285 (Serum uric acid estimation: chemical and enzymatic methods compared).

Dencker, S. J., Hauge, M., Kaij, L., and Nielsen, A. (1961). Acta genet. (Basel), 11, 265 (The use of anthropological traits and blood groups in the determination of the zygosity of twins).

Greig, W. R., Boyle, J. A., Duncan, A., Nicol, J., Gray, M. J. B., Buchanan, W. W., and McGirr, E. M. (1967). Quart.J. Med., 36, 142. (Genetic and non-genetic factors in simple goitre formation: evidence from a twin study).

Hauge, M., and Harvald, B. (1955). Acta med. scand., 152, 247 (Heredity in gout and hyperuricaemia).

Jensen, J., Blankenhorn, D. H., Chin, H. P., Sturgeon, P., and Ware, A. G. (1965). J. Lipid Res., 6, 193 (Serum lipids and serum uric acid in human twins).

Mathers, J. A. L., Osborne, R H., and De George, F. V. (1961). Amer. Heart J., 62, 634 (Studies of blood pressure, heart rate, and the electrocardiogram in adult twins).

O'Brien, W. M., Burch, T. A., and Bunim, J. J. (1966). Ann. rheum. Dis., 25, 117 (Genetics of hyperuricaemia in Blackfeet and Pima Indians).

Osborne, R. H., and De George, F. V. (1959). "Genetic Basis of Morphological Variation". Harvard University Press, Cambridge, Mass. 
Seegmiller, J. E., Laster, L., and Howell, R. R. (1963). New Engl. J. Med., 268, 712, 764, 821 (Biochemistry of uric acid and its relation to gout).

Smyth, C. J., Cotterman, C. W., Freyberg, R. H., Jr. (1948) J. clin. Invest., 27, 749 (The genetics of gout and hyperuricemia -an analysis of 19 families).

Stecher, R. M., Hersh, A. H., and Solomon, V. M. (1949). Ann. intern. Med., 31, 595 (The heredity of gout and its relationship to familial hyperuricemia).

Rôles relatifs des facteurs génétiques et du milieu ambiant dans le maintien du niveau de l'acide urique sanguin chez des sujets normouricémiques

RÉsumé

On détermina le taux sérique de l'acide urique par une méthode colorimétrique automatique chez 112 paires de jumeaux sains de la ville Glasgow et de l'Ecosse de l'Ouest. Le calcul des variances intrapaires pour les jumeaux monozygotes et dizygotes démontra l'existence d'un composant génétique significatif affectant le taux de l'acide urique sanguin chez les femmes. On ne réussit à déceler aucun composant génétique fort chez les hommes. On discute la possible existence d'un facteur (ou facteurs) du milieu ambiant jouant un rôle important dans le maintien des taux uricémiques plus élevés chez les hommes par rapport aux femmes.
Papeles relativos de los factores genéticos y del medio ambiente en el mantenimiento del nivel del ácido úrico en el suero de sujetos normouricémicos

\section{SUMARIO}

Se determinó por un método colorimétrico automatizado el nivel del ácido úrico en el suero de 112 parejas de gemelos sanos de la ciudad de Glasgow y de Escocia occidental. La calculación de las variaciones intragemelas en parejas mono y dicigóticas reveló la existencia de un componente genético significativo afectando las cifras del ácido úrico en el suero de las mujeres. No se llegó a descubrir tal componente en el suero de los hombres. Se discute la posible existencia de un factor (o factores) del medio ambiente desempeñando un papel importante en el mantenimiento del nivel uricémico más alto en los hombres que en las mujeres. 